\title{
Best Management Practices in the Everglades Agricultural Area: Controlling Particulate Phosphorus and Canal Sediments ${ }^{1}$
}

O.A. Diaz, T.A. Lang, S.H. Daroub, and M. Chen $^{2}$

\section{Introduction}

Long-term changes in the Everglades ecosystem are of critical concern in the development of a restoration plan for the Everglades. Stormwater runoff from the Everglades Agricultural Area (EAA) is a major source of water to the Water Conservation Areas and Everglades National Park in South Florida. However, increased concerns regarding runoff water quality from the EAA basin, specifically phosphorus $(\mathrm{P})$, and its environmental impact on the Everglades wetland ecosystems led to the development of a regulatory program in the EAA that required $\mathrm{P}$ levels in drainage waters leaving the basin to be reduced by at least $25 \%$ relative to historic levels. Farmers of the EAA have responded to the challenge to achieve this $\mathrm{P}$ load reduction by implementing Best Management Practices (BMP) programs on their farms, which includes monitoring their individual farm discharge waters for flow volume and $\mathrm{P}$ concentration.

The South Florida Water Management District has developed a BMP table that lists the BMP practices that have been designed to reduce particulate $\mathrm{P}$ and sediment loads in drainage waters from EAA farms. The purpose of this document is to explain and discuss these particulate $\mathrm{P}$ and sediment control practices. These practices serve as important tools in efforts to improve water quality in the basin. This EDIS article is one in a series that attempts to explain in easily understandable terms the implementation methods and rationale behind the main $\mathrm{P}$ load reducing BMPs employed on EAA farms.

In watersheds draining agricultural areas, $\mathrm{P}$ can be transported in soluble and particulate forms. Particulate $\mathrm{P}$ consists of all solid phase forms, which includes $\mathrm{P}$ sorbed by soil particles and organic material transported during runoff. On-farm studies in the EAA by UF/IFAS researchers have shown that a significant portion of the total $\mathrm{P}$ load in drainage water leaving farms is in the particulate form. More recent UF/IFAS studies confirmed that particulate $\mathrm{P}$ accounted for $20 \%$ to $70 \%$ of the total P exported from EAA farms. Efforts targeting the reduction of particulate $P$ and sediments in farm drainage waters are important to further reduce the total $\mathrm{P}$ load at the farm level. Thus, the use of any practice specifically

1. This document is SL228, a fact sheet of the Soil and Water Science Department, Florida Cooperative Extension Service, Institute of Food and Agricultural Sciences, University of Florida. Original publication date Aug 2005. Visit the EDIS Web Site at http://edis.ifas.ufl.edu.

2. O. A. Diaz, T. A. Lang, and M. Chen, Research Associates and S. H. Daroub, Assistant Professor, University of Florida Institute of Food and Agricultural Science, Everglades Research and Education Center, Belle Glade, FL.

The Institute of Food and Agricultural Sciences (IFAS) is an Equal Opportunity Institution authorized to provide research, educational information and other services only to individuals and institutions that function with non-discrimination with respect to race, creed, color, religion, age, disability, sex, sexual orientation, marital status, national origin, political opinions or affiliations. U.S. Department of Agriculture, Cooperative Extension Service, University of Florida, IFAS, Florida A. \& M. University Cooperative Extension Program, and Boards of County Commissioners Cooperating. Larry Arrington, Dean 
directed to the reduction of particulate $\mathrm{P}$ can considerably influence the total P load leaving the farm.

\section{Leveling of Fields}

Even though most agricultural fields in the EAA are relatively flat and uniform, prior to planting the main crops of the area, i.e., sugarcane, sod, vegetables, and rice, fields may require additional leveling by precision land-leveling machinery (laser and GPS guided land-leveling equipment; Figure 1). The main $\mathrm{P}$ load reduction rationale for performing field leveling is that it reduces the potential for soil erosion into field ditches and drainage canals due to sheet flow after heavy rainfall. A level field has less chance of sheet and rill erosion occurring, which is especially important since agricultural fields in the EAA are often exposed to intense rainfall events that occur regularly in south Florida.

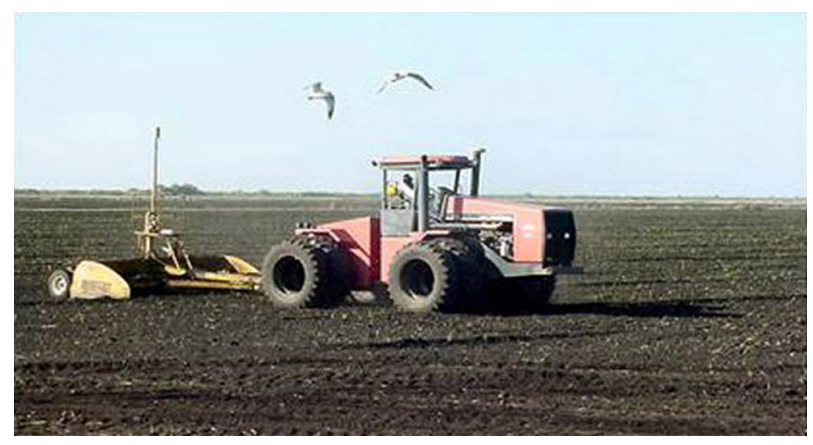

Figure 1. Land-leveling reduces sheet erosion and improves water management.

A secondary benefit to $\mathrm{P}$ load reduction by land leveling is the improvement in field drainage and irrigation efficiency across the field. Leveled fields drain and irrigate more uniformly relative to the soil surface, thus reducing the likelihood of improperly draining and irrigating lower and higher areas of the field. Over-draining the majority of a field to achieve required soil dryness in low-lying areas of the field will unnecessarily add to farm P load by increasing the volume of drainage water required to adequately drain the field. In addition, over-irrigation is required to wet the elevated areas of the field, which may result in reduced crop yields in low-lying areas of the field and will result in increased irrigation water requirements.
In sugarcane production, fields are usually leveled prior to planting a cover crop such as rice or after cessation of a flooded fallow. This improves the water management of the rice crop as well as the succeeding plant cane crop. Laser-guided leveling machinery has been in use for years in the EAA, currently there are a few EAA growers using the more robust GPS-guided leveling machinery due to its better performance under all weather conditions.

\section{Ditch and Canal Bank Berms}

The main objective of this practice is to minimize agricultural field surface runoff that may transport soil and associated nutrients from agricultural fields into field ditches and drainage canals. It is implemented by constructing small raised berms parallel to the ditch and canal banks that surround EAA fields (Figure 2). During construction of berms along field ditches, part of the organic soil along the ditch banks is used to build a small mound that will block runoff from fields from eroding directly into field ditches. The water that may pond on the surface of a field is then forced to percolate down vertically into the soil, eliminating the transport of soil via sheet and rill erosion after heavy rainfall events. When rock material dug from field ditches is available, a layer of broken rock, later covered with soil material, is laid along the ditch banks to build a small berm.
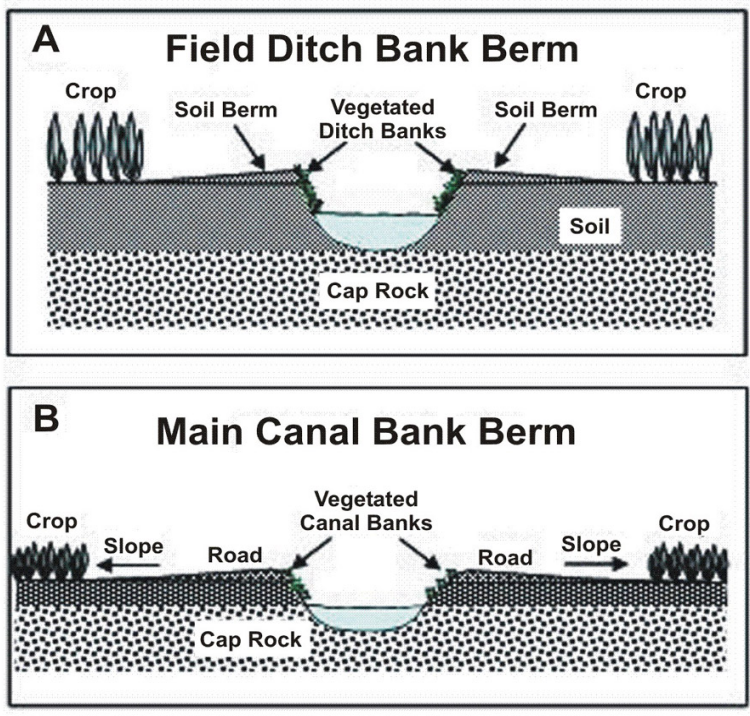

Figure 2. Schematic diagram of A) field ditch berm and B) main canal bank berm. 
Berms constructed beside drainage canals also control runoff material along roads that may otherwise end up in canal drainage waters. Road materials may contain residuals from fertilizer and pesticide applications. The berms constructed alongside canals effectively halt the occurrence of road material runoff into the canal. Roads with canals berms should also be graded to have a slight inclination downward towards the field and away from the canal to ensure any surface water movement off the road will be towards the field and not the canal.

\section{Main Canal Sediment Sumps and Traps}

The main objective of this sediment control BMP practice is to deepen and/or widen a section of a main drainage canal upstream of drainage pump structure to reduce flow velocity and trap the heavier sediment material before it is pumped off the farm. Depending upon the farm canal configuration, sediment sumps are generally constructed at a distance of 100 to 1000 $\mathrm{ft}$ (or more) upstream of the drainage pump station. The dimensions of the sump will depend on the size of the canal, the operating flow range of the pump station and the target drainage flow velocity (Figure 3). Sumps constructed upstream of drainage pumps should be cleaned regularly to remain effective. Maintenance and cleaning of sumps should be combined with the regular canal/ditch cleaning program of the farm, with the sediment material placed back into production fields.

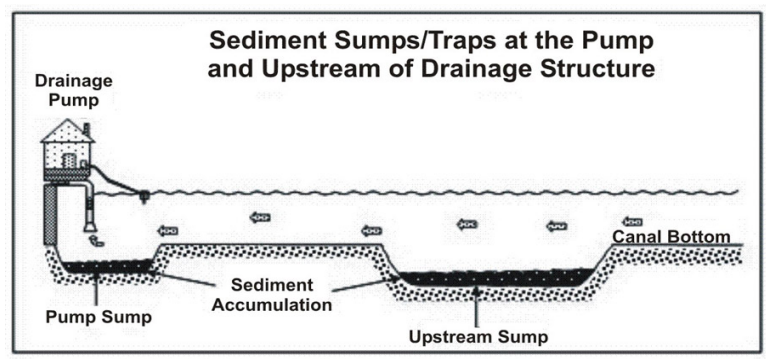

Figure 3. Schematic diagram of a main canal sediment sump.

Sediment sumps and traps in geographical areas other than South Florida have been shown to remove 60 to $90 \%$ of the suspended sediment in drainage water. Sediment trap efficiency is directly correlated with sediment retention. Brown et al. (1981) reported that sediment traps were able to remove 65 to $76 \%$ of the sediment, and 25 to $33 \%$ of the total P entering the trap. The effectiveness of sediment trap techniques in the EAA has not been sufficiently tested or verified. However from some preliminary studies in the EAA, (Stuck et al., 2001) it is thought that they will not yield the same results observed in other areas of the country. Most particulate matter in drainage waters leaving the EAA farms is very light, is easily suspended, and requires a long residence time in the sediment sumps or traps in the drainage canals in order to settle out of the water column. However, there is a considerable fraction of an EAA farm's particulate $\mathrm{P}$ load that is heavier and may be amenable to removal by sediment sumps in the EAA (Stuck et al., 2001; Daroub et al., 2003).

\section{Sediment Sumps in Field Ditches}

Construction of sumps in field ditches has become one of the most commonly used sediment control BMP practices in the EAA. The dimensions of field ditch sumps can vary from farm to farm, but it is basically a sump of about $20 \mathrm{ft}$ long, $6 \mathrm{ft}$ wide and 3 to $5 \mathrm{ft}$ deep, dug into the caprock just before the mouth of a culvert draining into a farm drainage canal (Figures 4 and 5). The main objective of this sediment control BMP practice is to trap the heavier sediments that have been deposited in field ditches during field preparation, by wind erosion, and by surface water runoff, before it is transported into main drainage canals. Growers that use field ditch sumps have observed that this is an effective BMP practice and reduces considerably the amount of sediment that would otherwise reach the main drainage canal and potentially be discharged off the farm. However, field ditch sumps need to be cleaned as they fill with sediment, usually every other year to maintain their effectiveness in trapping sediments. Maintenance and cleaning of sumps should be combined with the regular canal/ditch cleaning program of the farm and the sediment material put back into adjacent fields.

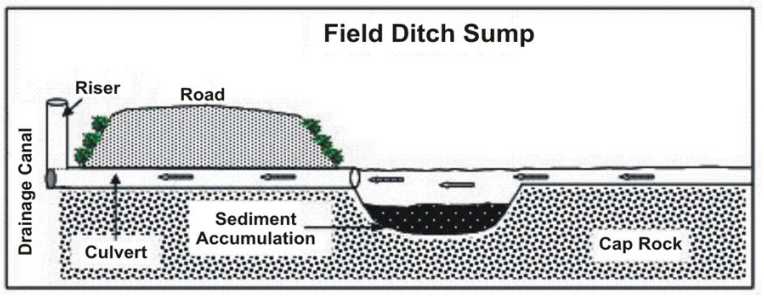

Figure 4. Schematic diagram of field ditch sump. 


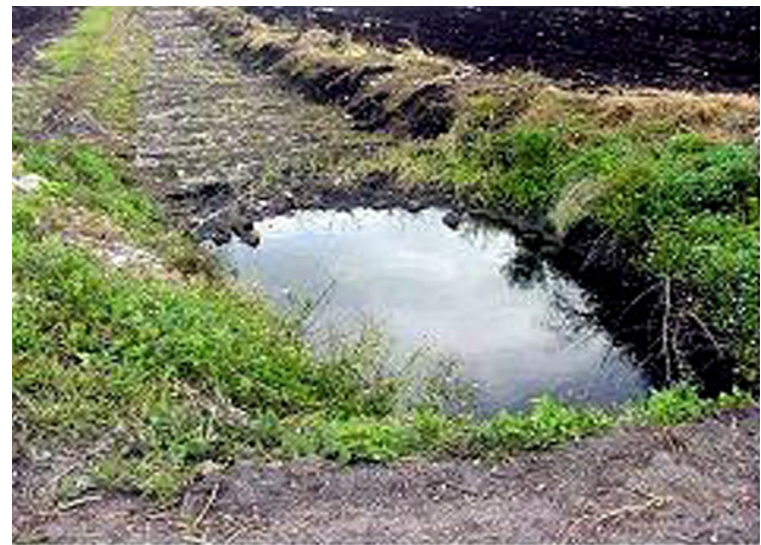

Figure 5. Typical field ditch sediment sump.

\section{Regular Canal and Field Ditch Cleaning}

Sediment surveys of selected farm drainage canals in the EAA showed that sediments tend to accumulate in main drainage canals upstream of drainage structures. The sediment survey reported that there was sufficient $P$ in the accumulated sediments to supply particulate $\mathrm{P}$ for several years, if the sediment is not removed.

Depending on the specific farm hydraulic system and its management, there is generally a layer of light sediment flock material accumulated at the interface between the sediment bed and water column in the canal that is high in $\mathrm{P}$ content. This organic floc material is easily suspended and transported during both weak and strong drainage events. Therefore, a diligent canal cleaning program is an essential practice to eliminate sediment material that has accumulated in the canal systems. If these sediments are not removed they have the potential to be transported off the farm during drainage events (Figure 6). Canal cleaning should be conducted during quiescent conditions or if possible in conjunction with irrigation to relocate sediment resuspended during the cleaning to the upstream reaches towards the back of the farm. In-stream biological growth in main farm canals is the primary contributor to particulate $\mathrm{P}$; thus, it is important to concentrate the efforts and clean regularly the canal sections directly upstream of main drainage structures. In addition drainage pumping during or immediately after canal cleaning is to be avoided so as not to release drainage waters of high sediment concentration.

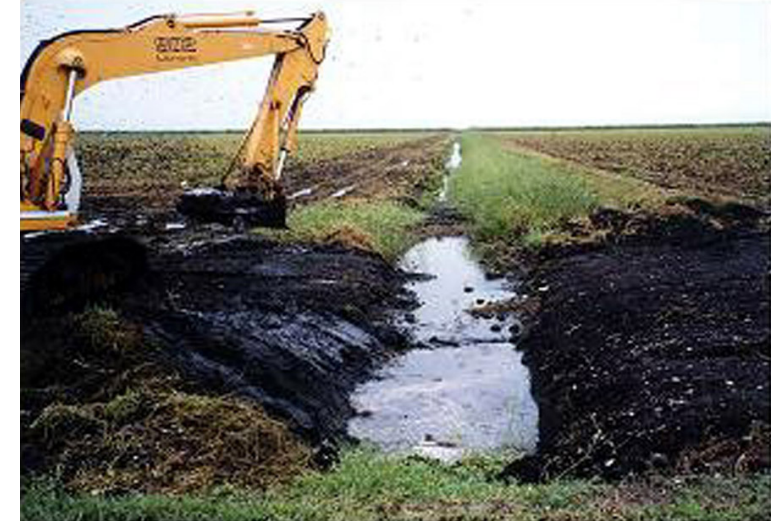

Figure 6. Removal of soil and sediment buildup in field ditches.

\section{Slowed Drainage in Fields near Exit Pump Stations}

Slowing and preventing the over-draining of fields close to the farm drainage station is another sediment control BMP practice available to growers in EAA basin. Implementation of this practice involves the installation of culverts with risers in field ditches that serve to drain fields located near main drainage pumps and subsequent placement of flow-restraining boards into the risers to slow drainage (Figure 7). The purpose of this practice is to have the flexibility to use boards in the risers to slow drainage rates in the fields near the pump station and allow fields located at farther distances from the pump station to drain at similar rates and to a similar depth as those located closer to the pump station. This practice reduces the amount of drainage water leaving the fields near the pump station. In effect it reduces the need to over-drain fields closest to the pump station in order to achieve drainage from fields that are located farther upstream from the drainage pump station.

A secondary goal of this practice is to slow the velocity in ditches and canals draining fields near the main pump station. If drainage flow velocities of ditches and canals near the pump station are not slowed by constricting flow -- in this case through installation of riser boards -- the high velocities have the potential to transport particulate $\mathrm{P}$ and sediments from the field ditches into the main canal drainage stream and quickly move off-farm. Culverts serving fields located farther upstream are not subjected to the same flow velocities as those near the pump 


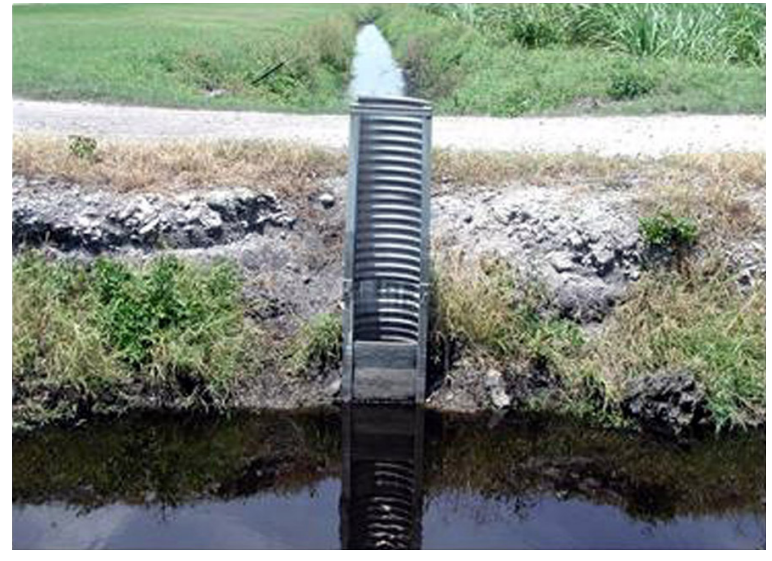

Figure 7. Riser boards slow drainage near pumps.

station, since in most cases, the difference between canal water level and field ditch water level (head difference) will not be as great as the difference between field ditch water level and the main canal water level near the pump station.

\section{Use of Cover Crops}

A cover crop is a crop grown to provide soil cover to minimize soil loss to erosion, regardless of whether the cover crop is later incorporated into the soil. A Natural Resources Conservation Service definition of cover crop is "grasses, legumes, forbs, or other herbaceous plants established for seasonal cover and conservation purposes." Cover crops are grown primarily to prevent soil erosion by wind and water. Cover crops can be annual, biennial, or perennial herbaceous plants grown in a pure or mixed stand during all or part of the year. In addition to providing ground cover and, in the case of a legume, fixing nitrogen, they may also help suppress weeds and reduce insect pests and plant diseases. When cover crops are planted to reduce nutrient leaching following a main crop, they are often termed "catch crops." For a predominantly vegetable production farm in the EAA two examples of possible catch crops would be sugarcane and rice.

Soil loss due to wind erosion and water runoff is markedly increased in fallow fields that are left unplanted or unprotected during the spring and summer months. Fields left unplanted after land preparation are especially vulnerable to serious soil losses due to wind erosion and water runoff and become potential sources of organic matter in the drainage waters and may contribute to the total P load leaving the farm. The planting of cover crops on fallow fields is a sediment control BMP that has been approved for implementation in the EAA. Flooded field crops such as rice and flooded fallow fields have been proven to be very effective in reducing soil losses due to wind and water erosion and in addition stop soil oxidation. (Figure 8). Incorporation of high biomass cover crops into organic soils has the additional benefit of increasing the organic content of the soil, making it more stable and less prone to erosion.

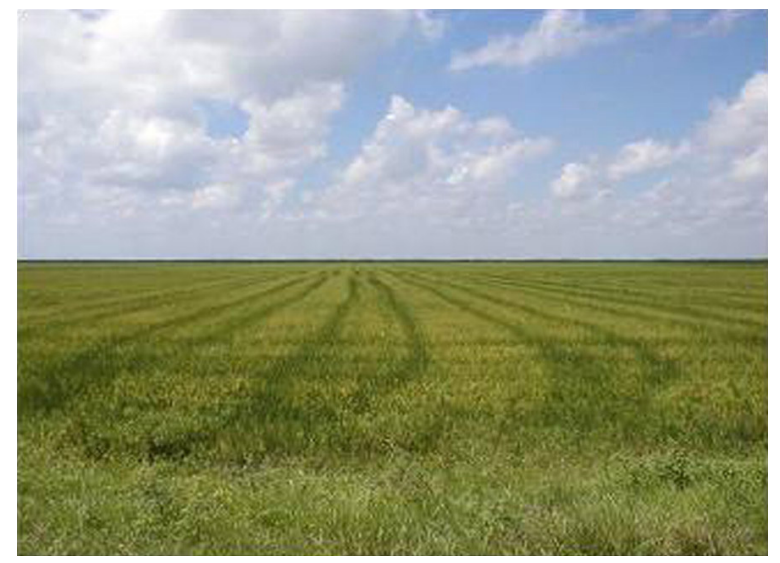

Figure 8. Cover crop of rice stops soil erosion and subsidence.

\section{Installation of Raised Culverts}

The use of raised culverts is another sediment control BMP practice that has been widely accepted and implemented by the growers of the EAA basin. The implementation technique for this practice is to install culverts that join field ditches with adjoining canals at a calculated and measured height above the ditch or canal bottom to reduce the chance of sediment transport during drainage events and consequent discharge off farm (Figure 9). This sediment control practice can be combined with the construction of a sump at the entrance of the culvert to take advantage of sediment trapping in the sump. The sediment accumulated in the sump or depression around the entrance of the culvert needs to be regularly removed for this practice to remain effective. Maintenance and cleaning should be included with the regular canal/ditch cleaning program of the farm and any sediment material removed from ditches and canals should be put back into adjacent fields. 


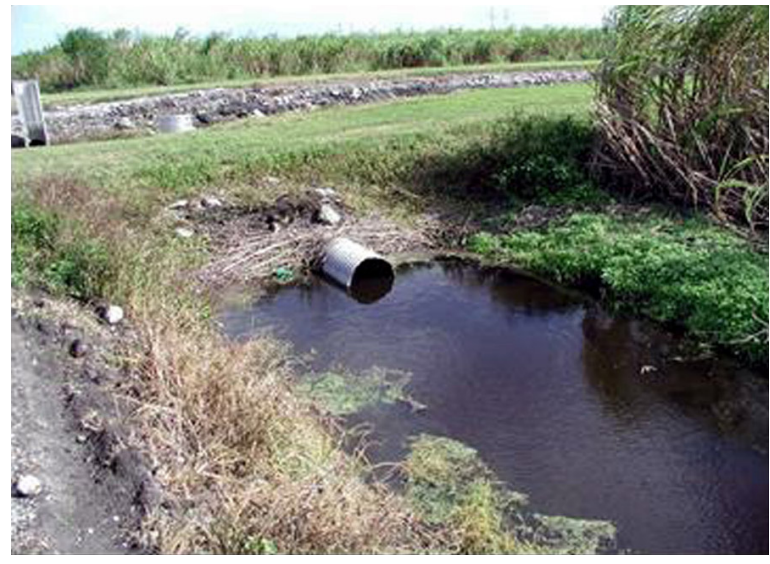

Figure 9. Raised culvert bottom reduces bedload sediment transport.

Raised culverts effectively serve as barriers to the transport of the heavier sediments and soil particles that may enter the drainage flow from field ditches under high velocity conditions. High flow velocity in field ditches may occur during conditions of high flow drainage coupled with concurrent intense rainfall. Installing culverts that are raised slightly relative to the ditch bottom and coupling them with ditch sumps are two effective measures to reduce sediment transport off EAA farms.

\section{Vegetated Ditch Banks for Stabilization}

Bare or non-vegetated ditch and canal banks can be potential sources of sediment materials that can be eroded and transported into drainage waters during rainfall events. The main objective of this sediment control BMP practice is to reduce the amount of runoff bank sediments by protecting ditch and canal banks with a vegetative cover (Figure 10).

Vegetative growth, especially grasses such as Bermuda, Bahia, or St. Augustinegrass can be used to stabilize and protect the ditch and canal banks. The plant specie should posses extensive root systems capable of holding the soil in place and be vigorous to provide the plants with sufficient moisture during the dry spring season, i.e., they should maintain healthy cover and growth during the entire year to effectively protect the bank from erosion. Banks generally need to be maintained and mowed regularly to control weeds and reduce the amount of dense vegetative cover favored by rodents.

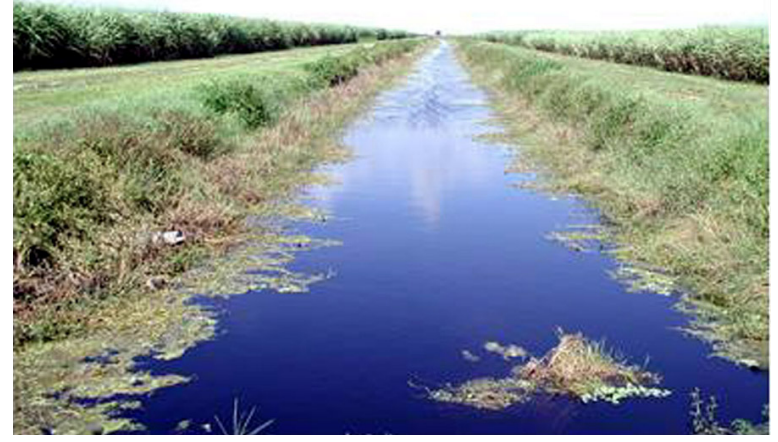

Figure 10. Stabilization of canal banks with vegetation.

\section{Use of Weed Booms and Trash Racks}

As previously stated, a significant part of the total P load leaving the EAA basin is in the particulate $\mathrm{P}$ form fraction. Studies by Stuck et al. (2001) demonstrated that floating aquatic weeds had $\mathrm{P}$ contents similar to the exported suspended solids of study farms. They also demonstrated that a large fraction of the floating aquatic weed mass was dislodgable, which would allow it to contribute directly to P export. Results from sediment transport and floating aquatic plant $\mathrm{P}$ cycling studies provide strong evidence that floating aquatic plants may be the principal source of exported particulate $\mathrm{P}$ from EAA farms (Stuck et al., 2001; Daroub et al., 2003). Thus limiting the growth of floating aquatic vegetation in main canals, especially upstream of drainage structures, is a very important particulate $\mathrm{P}$ and sediment control practice.

Readily suspended flocculent organic material (plant detritus) is high in $\mathrm{P}$ content and difficult to control by conventional sediment control practices. An aggressive floating aquatic vegetation control program is the most productive method to reduce the supply of high $\mathrm{P}$ content particulate material. The installation of weed-retention booms or trash racks (Figure 11) well upstream (installation distance will depend on size of main canal) of drainage structures are recommended to reduce the amount of particulate $\mathrm{P}$ transported off the farm during drainage events. Herbicidal control of dense infestations of floating aquatic weeds, although not recommended, is often the only option available to achieve moderate to complete reduction of growth and control of the 
floating weed biomass. After herbicide application, the resultant dead plant material usually provides large amounts of easily transportable organic floc material. If the herbicide application can be timed with heavy irrigation periods in late spring, then most of the plant detritus may be relocated and deposited well upstream of the drainage pump station. Subsequent herbicidal control of floating weeds should be limited to spot spraying of weedy areas to minimize the impact and keep the aquatic vegetation growth to a minimum.

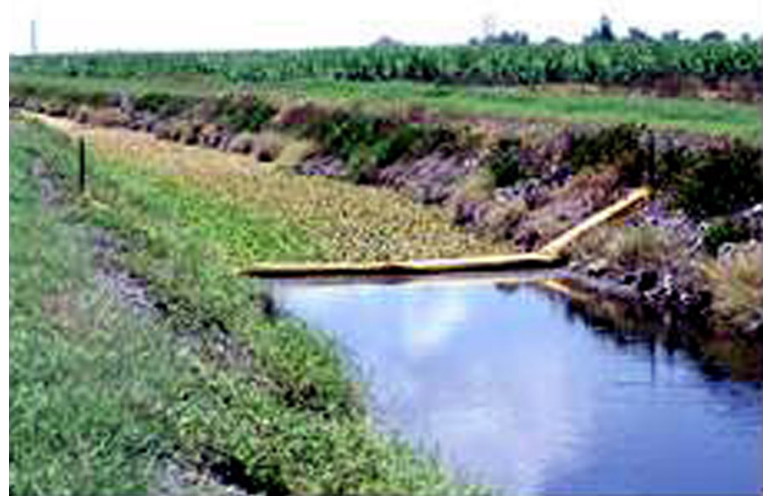

Figure 11.a

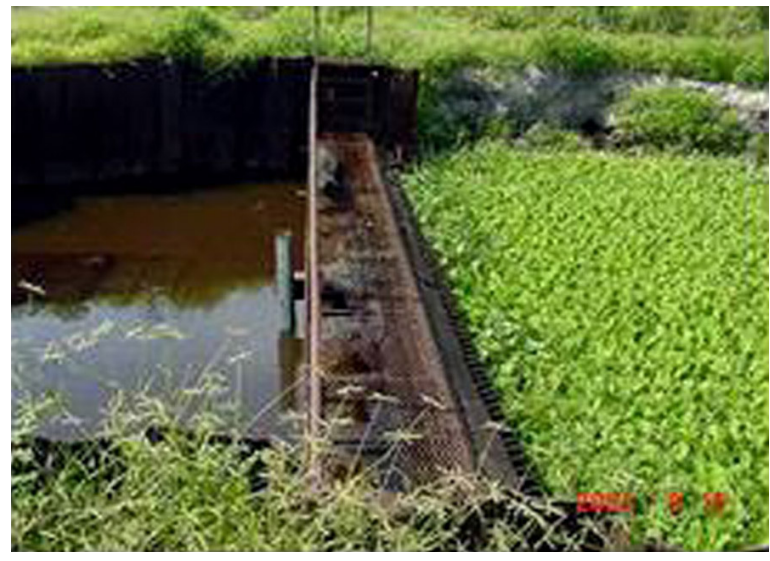

Figure 11.b

Figure 11. Weed booms (a) and trash racks (b) keep aquatic weeds from drainage pumps.

For information concerning specific control practices of aquatic weeds, please search the numerous EDIS publications on aquatic weed management by V. Vandiver, Jr, K. Langeland, and others at http://edis.ifas.ufl.edu/.

\section{Summary}

Particulate $\mathrm{P}$ and sediment control practices are integral to each EAA farm's efforts to reduce its off-farm P loads. The main control practices briefly discussed in this publication include:

- Leveling of fields;

- Ditch and canal bank berms;

- Main canal sediment sumps and traps;

- Sediment sumps in field ditches;

- Regular canal and field ditch cleaning;

- Slowed drainage near exit pump stations;

- Use of cover crops;

- Installation of raised culverts;

- Vegetated ditch banks for stabilization;

- Use of weed booms and trash racks.

For additional information concerning Phosphorus BMPs in the EAA, please contact your county extension agent or IFAS personnel at the Everglades Research and Education Center in Belle Glade, FL or the Soil and Water Science Department of the University of Florida in Gainesville.

\section{Acknowledgements}

The authors are grateful for the financial support of the Everglades Agricultural Area-Environmental Protection District and the Florida Department of Environmental Protection for the preparation of this document and also conducting the associated BMP studies described within it. Gratitude is also extended to John Menhennett and Luis Girado for providing many of the pictures presented in this publication.

\section{References}

Brown, M.J., J.A. Bondurant, and C.E. Brockway. 1981. Ponding surface drainage water for sediment and phosphorus removal. Trans. Am. Soc. Agric. Eng. 24:1478-1481. 
Daroub, S.H., J.D. Stuck, T.A. Lang, O.A. Diaz, and M. Chen. 2003. Implementation and verification of BMPs for reducing P loading in the EAA. Final Project Report submitted to the Everglades Agricultural Area Environmental Protection District and The Florida Department of Environmental Protection, Tallahassee, FL.

Izuno, F.T., C.A. Sanchez, F.J. Coale, A.B. Bottcher, and D.B. Jones. 1991. Phosphorus concentrations in drainage waters in the Everglades Agricultural Area. J. Environ. Qual. 20:608-619.

Izuno, F.T., and R.W. Rice. 1999.

Implementation and verification of BMPs for reducing $\mathrm{P}$ loading in the EAA. Final project report submitted to the Florida Department of Environmental Protection and the Everglades Agricultural Area Environmental Protection District, Tallahassee, FL.

LOTAC. 1990. Lake Okeechobee Technical Advisory Council Final Report. Tallahassee, Fla., Florida Department of Environmental Protection.

Robbins, C.W., and D.L. Carter. 1975. Conservation of sediment in irrigation runoff. J. Soil Water Conserv. 30:134-135.

Schuman, G.E., R.G. Spomer, and R.F. Piest. 1973. Phosphorus losses from four agricultural watersheds on Missouri Valley loess. Soil Sci. Soc. Am. Proc. 37:424-427.

Sharpley, A.N., T.C. Daniel, and D.R. Edwards. 1993. Phosphorus movement in the landscape. J. Prod. Agric. 6:492-500.

Sharpley, A.N., and A.D. Halvorson. 1994. The management of soil phosphorus availability and its impact on surface water quality. In R. Lal and B.A. Stewart (eds.) Soil Processes and Water Quality. Lewis Publishers, Boca Raton, FL.

Sievers, P., D. Pescatore, S. Daroub, J.D. Stuck, J. Vega, P. McGinnes, and S. Van Horn. 2003. Performance and Optimization of Agricultural Best Management Practices. In Water Year 2002, Everglades BMP Program Annual Report,
South Florida Water Management District, West Palm Beach, FL.

Stuck, J.D., F.T. Izuno, K.L. Campbell, A.B. Bottcher, and R.W. Rice. 2001. Farm-level studies of particulate phosphorus transport in the Everglades Agricultural Area. Trans. ASAE 44:1105-1116.

Whalen, P.J., J. VanArman, J. Milliken, D. Swift, S. Bellmund, D. Worth, T.D. Fontaine, L.Golick, and S. Formati. 1992. Surface water improvement and management plan for the Everglades. South Florida Water Management District, West Palm Beach, FL. 